\title{
G9a: An Emerging Epigenetic Target for Melanoma Therapy
}

\author{
Jessica L. Flesher (1) and David E. Fisher *
}

Cutaneous Biology Research Center, Department of Dermatology, Massachusetts General Hospital, Harvard Medical School, Charlestown, MA 02129, USA; jflesher@mgh.harvard.edu

* Correspondence: dfisher3@mgh.harvard.edu; Tel.: +1-617-643-5428

\section{check for}

updates

Citation: Flesher, J.L.; Fisher, D.E. G9a: An Emerging Epigenetic Target for Melanoma Therapy. Epigenomes 2021, 5, 23. https://doi.org/10.3390/ epigenomes 5040023

Academic Editor: Ivana De la Serna

Received: 1 September 2021

Accepted: 4 October 2021

Published: 12 October 2021

Publisher's Note: MDPI stays neutral with regard to jurisdictional claims in published maps and institutional affiliations.

Copyright: (c) 2021 by the authors. Licensee MDPI, Basel, Switzerland. This article is an open access article distributed under the terms and conditions of the Creative Commons Attribution (CC BY) license (https:// creativecommons.org/licenses/by/ $4.0 /)$.

\begin{abstract}
Epigenetic regulation is a crucial component of DNA maintenance and cellular identity. As our understanding of the vast array of proteins that contribute to chromatin accessibility has advanced, the role of epigenetic remodelers in disease has become more apparent. G9a is a histone methyltransferase that contributes to immune cell differentiation and function, neuronal development, and has been implicated in diseases, including cancer. In melanoma, recurrent mutations and amplifications of G9a have led to its identification as a therapeutic target. The pathways that are regulated by G9a provide an insight into relevant biomarkers for patient stratification. Future work is aided by the breadth of literature on G9a function during normal differentiation and development, along with similarities to EZH2, another histone methyltransferase that forms a synthetic lethal relationship with members of the SWI/SNF complex in certain cancers. Here, we review the literature on G9a, its role in melanoma, and lessons from EZH2 inhibitor studies.
\end{abstract}

Keywords: G9a; epigenetic inhibitors; melanoma; EZH2

\section{Epigenetic Regulation by Histone Methyltransferases}

While DNA encodes all the necessary genes, the reversible modifications to DNA and histone complexes allows for one individual to undergo development from a zygote to a complex multi-cellular organism. Open chromatin that is permissive for transcription is often marked with nearby histone acetylation. Depending on the context, histone methylation can provide active marks, such as histone 3 lysine 4 (H3K4), but are more often associated with repression through $\mathrm{H} 3 \mathrm{~K} 9$ and $\mathrm{H} 3 \mathrm{~K} 27$ methylation found near compacted chromatin that is inaccessible for transcription [1]. Additional modifications to histones include phosphorylation, ubiquitination, and sumoylation, which alter transcription and repair, while DNA can be modified through methylation to alter transcription [2]. Together, histone modifications and DNA methylation tightly regulate chromatin accessibility within cells.

Histone methyltransferases are members of a large family of proteins that require the methyl group donor s-adenosyl-methionine (SAM) to methylate specific residues on the histone tail, or add to previously methylated residues to form di- and trimethylation. Histone 3 lysine 9 (H3K9) is initially methylated by G9a (EHMT2 gene) and GLP (EHMT1 gene) dimers to form activating $\mathrm{H} 3 \mathrm{~K} 9$ monomethylation, and it is further methylated by G9a to form repressive H3K9 dimethylation (H3K9me2) [3], as illustrated in Figure 1. Both G9a and GLP contain ankyrin repeats to recognize these methylation residues, and an SET domain that is required for catalytic activity that utilizes SAM. The G9a/GLP complex is required for methyltransferase activity, since a loss of either G9a or GLP can significantly reduce $\mathrm{H} 3 \mathrm{~K} 9 \mathrm{me} 2$ in the brain [4]. While there is some evidence that G9a may facilitate the trimethylation of $\mathrm{H} 3 \mathrm{~K} 9$, the histone methyltransferase SETDB1 is critical for maintaining the DNA methylation of retrotransposons through H3K9me3 [5], while SUV39H1 and $\mathrm{SUV} 39 \mathrm{H} 2$ deposit the trimethylation of $\mathrm{H} 3 \mathrm{~K} 9$ at constitutive heterochromatins [6]. This means that G9a directly contributes to repressive dimethylation and subsequent trimethylation at $\mathrm{H} 3 \mathrm{~K} 9$ throughout the genome. 


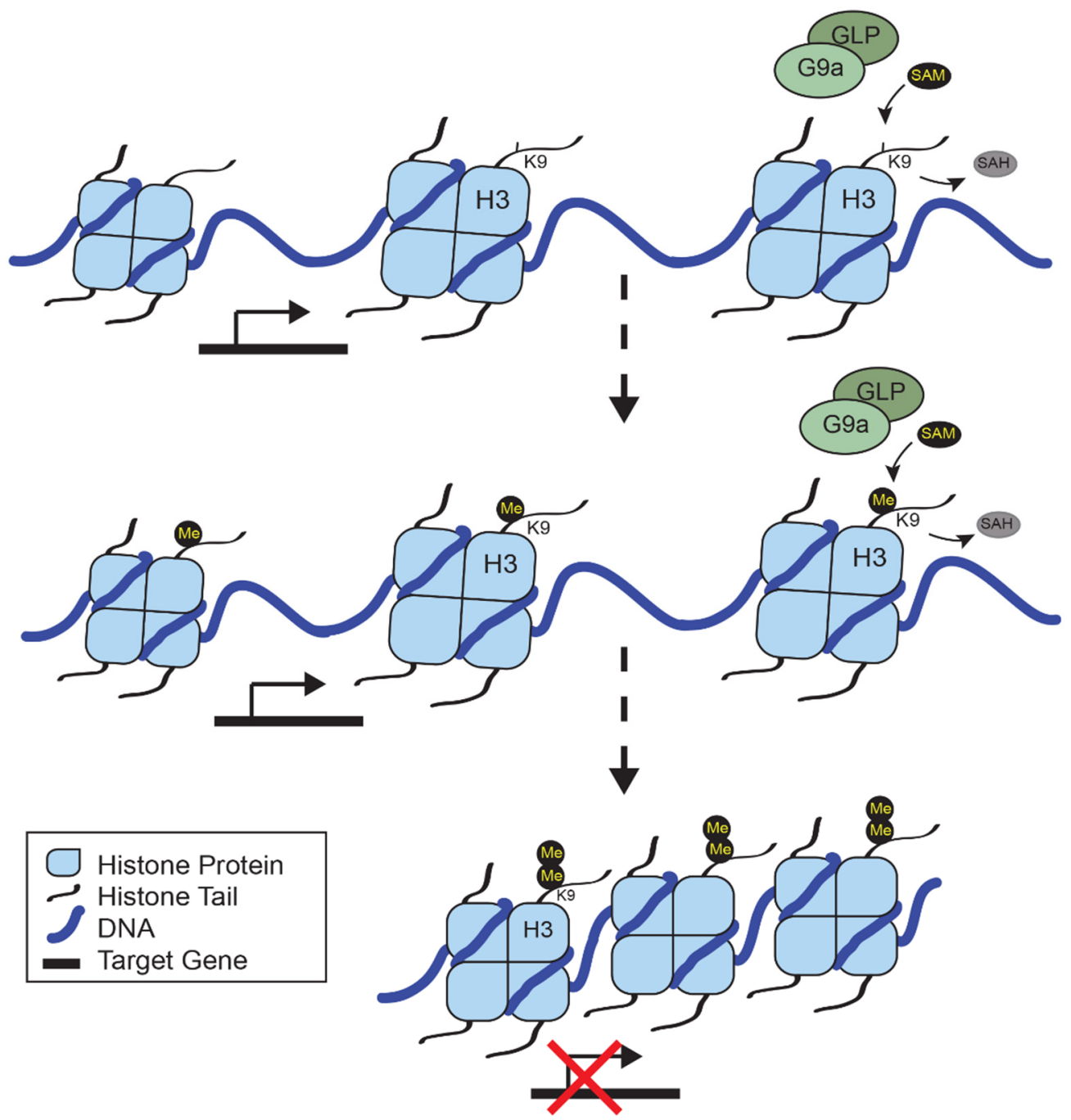

Figure 1. G9a-dependent methylation of H3K9 leads to transcriptional repression. G9a forms a dimer with GLP which recognizes histone 3 lysine 9 (H3K9) for methylation. Using SAM (sadenosyl-methionine) as the methyl donor, G9a transfers a methyl group (Me) to generate H3K9 monomethylation (H3K9me), releasing SAH (s-adenosyl homocysteine). G9a/GLP dimers further methylate $\mathrm{H} 3 \mathrm{~K} 9 \mathrm{me}$ to generate dimethylation (H3K9me2). At sites where $\mathrm{H} 3 \mathrm{~K} 9 \mathrm{me} 2$ is present, chromatin is compacted leading to transcriptional repression of target genes.

Though histone methyltransferases are thought to function specifically in histone regulation, G9a can also methylate proteins with histone methylation site-like residues. G9a itself has an automethylation site near the $\mathrm{N}$-terminus that increases functional activity and interaction with HP1, a protein enriched in euchromatin [7]. G9a can methylate additional non-histone proteins in complex with GLP, or alone, modulating proteins including WIZ, a binding partner of G9a; HIF-1alpha, blocking the transcription activity of hypoxia target genes; p53, a key tumor suppressor; and HDAC1 and DMNT1, a histone deacetylase and DNA methyltransferase, respectively [8-10]. The number of G9a targets and its repressive role in gene expression both directly and indirectly showcase the impact that epigenetic regulators can have on a cell.

\section{The Role of G9a in Development and Differentiation}

During development and differentiation, cells actively open and close chromatin to turn off genes that were required for earlier states and turn on gene programs that facilitate proper differentiation. H3K9me2 is required during early embryonic development, since the constitutive loss of Ehmt2 causes embryonic lethality at 11.5 days and loss of the mater- 
nal copy alters DNA methylation during zygote development [11]. G9a also contributes to silencing Oct3/4 and Nanog during early embryonic development [9]. In embryonic stem cells, G9a has been implicated in the regulation of large organized chromatin K9 modifications [12], but additional analyses are necessary to validate the findings, as described by Filion and Steensel [13]. Altogether, G9a is required during development and represses key genes to allow for the differentiation of cell types.

G9a is also an important regulator of immune cell-type specific regulation. G9a and other methyltransferases regulate $\mathrm{T}$ cell fate decisions, as well as other lymphoid cells $[14,15]$. The transition from T-helper cells into functional CD8+ T cells relies on G9a to maintain the initial repression of $C D 4$ by RUNX3, so only the long-term maintenance of chromatin marks is effected by G9a loss [16]. The transcription factor BLIMP-1 also recruits G9a to promote CD8+ memory T cell terminal differentiation, by repressing Il2ra and Cd27 to stimulate an anti-viral response [17]. In B cells, G9a loss does not inhibit differentiation, but may affect the stability of mature B cells [18]. Additional evidence identified MHC class I proteins as targets for G9a repression [19]. Proteins that interact with G9a, including JARID2, also contribute to normal differentiation of additional immune cells, such as invariant natural killer T cells (iNKT) that are derived from CD4/CD8 double-positive T cells [20]. As an important regulator of immune differentiation, G9a contributes to both normal differentiation and the response to disease.

\section{The Oncogenic Roles of G9a in Melanoma}

Recent publications have identified G9a as a functional oncogene in melanoma, through recurrent activating mutations in the SET domain or through amplification of the genomic locus [21]. Some key pathways in melanoma are perturbed by G9a amplification, as summarized in Table 1. Wnt ligand signaling leads to a cellular cascade that prevents beta-catenin destruction allowing nuclear translocation in order to bind and promote transcription factors, such as LEF1. In melanocytes, the melanoma cell of origin, this process contributes to pigmentation, since several genes that are required for melanin synthesis are bound and transcriptionally activated via LEF1 [22]. Studies on Wnt signaling in melanoma have found that the stabilization of beta-catenin promotes tumor development and inhibits the response to immunotherapy in Braf ${ }^{V 600 E}$ mice with a loss of Pten [23,24]. Using the same melanoma model, the knockout of beta-catenin, which blocks Wnt signaling, inhibits tumor formation [23]. Wnt signaling can also be blocked through repressors, including DKK1, triggering beta-catenin degradation by the deconstruction complex, leading to the repression of Wnt target genes. DKK1 was found to be repressed by G9a overexpression in immortalized primary melanocytes, as well as upregulated when G9a was knocked down in melanoma cells [21]. While human melanoma in the TCGA shows a reverse relationship between G9a expression levels and immune signature genes, mouse studies in melanoma found that G9a inhibition, in combination with anti-PD-1 or anti-CTLA-4, increased survival compared to immunotherapy alone [21]. In neuroendocrine tumors, a loss of G9a or inhibition of H3K9me2 leads to the upregulation of DKK1/3 [25]. Similarly, in colorectal cancer, G9a and H3K9me2 marks are enriched at multiple known negative regulators of Wnt signaling, using patient-derived organoids [26]. Together, these studies highlight a possible mechanism through which G9a inhibition could modulate Wnt signaling, to both directly repress melanoma cell oncogenic behavior and increase responses to immunotherapy.

Another pathway that is altered by G9a inhibition and knockdown is Notch signaling [27]. Notch signaling relies on ligand binding to the notch receptor, leading to intracellular cleavage of the NICD domain that functions as a transcription factor for target genes. In melanoma, elevated Notch signaling has been linked to antitumor immunity [28], resistance to MEK inhibitors [29], and repression of MITF, leading to an invasive phenotype [30]. Notch signaling can also impact G9a, since an NICD-induced model of cholangiocarcinoma, a cancer arising in the bile duct, led to an increase in G9a levels, and subsequent tumors were sensitive to G9a inhibition [31]. Blocking Notch signaling within 
tumor cells may promote a less differentiated, treatment-resistant tumor; however, the inhibition of Notch signaling may not be entirely straight forward. Some evidence suggests that in melanoma-associated fibroblasts, Notch signaling decreases cell viability, creating a less favorable tumor microenvironment for the melanoma [32], and the loss of Notch signaling in fibroblasts can promote melanoma-initiating cells [33]. As with any targeting strategy, the possible benefits of G9a inhibition on tumor cells and the immune response will have to be weighed against the negative impacts on cancer-associated fibroblasts or other tumor microenvironment factors.

Table 1. Signaling pathways and cellular mechanisms linked to G9a in melanoma.

\begin{tabular}{|c|c|c|c|}
\hline $\begin{array}{l}\text { Signaling Pathway/ } \\
\text { Cellular Mechanism }\end{array}$ & Key Findings & Tumor Type & Reference \\
\hline \multirow{4}{*}{ Wnt Signaling } & $\begin{array}{l}\text { The Wnt repressor, DKK1, is targeted by } \\
\text { G9a repression }\end{array}$ & Melanoma & [21] \\
\hline & $\begin{array}{l}\text { Wnt signaling promotes melanoma } \\
\text { development and inhibits } \\
\text { immunotherapy response }\end{array}$ & Melanoma & {$[23,24]$} \\
\hline & $\begin{array}{c}\text { G9a loss or inhibition of H3K9me2 causes } \\
\text { upregulation of DKK1 }\end{array}$ & Neuroendocrine & [25] \\
\hline & $\begin{array}{l}\text { G9a is enriched at genes that negatively } \\
\text { regulate Wnt signaling in } \\
\text { patient-derived organoids }\end{array}$ & Colorectal Cancer & [26] \\
\hline \multirow{4}{*}{ Notch Signaling } & $\begin{array}{l}\text { Overexpression of G9a promotes upregulation } \\
\text { of Notch1 signaling pathway }\end{array}$ & Melanoma & [27] \\
\hline & $\begin{array}{l}\text { Elevated Notch signaling associated with } \\
\text { treatment resistance and more } \\
\text { invasive phenotypes }\end{array}$ & Melanoma & [28-30] \\
\hline & $\begin{array}{l}\text { Notch signaling in fibroblasts creates a less } \\
\text { favorable microenvironment }\end{array}$ & Melanoma & {$[32,33]$} \\
\hline & $\begin{array}{l}\text { G9a levels increase in NICD-induced model of } \\
\text { bile duct cancer }\end{array}$ & Cholangiocarcinoma & [31] \\
\hline \multirow{4}{*}{ Metastasis } & $\begin{array}{l}\mathrm{H} 3 \mathrm{~K} 9 \mathrm{me} 2 \text { is increased between non-metastatic } \\
\text { mesenchymal-like to metastatic melanoma cells }\end{array}$ & Melanoma & [34] \\
\hline & $\begin{array}{l}\text { HOX genes are upregulated in } \\
\text { metastatic melanoma }\end{array}$ & Melanoma & [35] \\
\hline & HOXA1 is a repressed target of G9a & Glioblastoma & [36] \\
\hline & $\begin{array}{l}\text { G9a represses CDH10 increasing cellular } \\
\text { motility during hypoxia }\end{array}$ & Breast Cancer & [37] \\
\hline \multirow{4}{*}{ Autophagy } & G9a inhibition activates autophagy & Melanoma & [38] \\
\hline & $\begin{array}{l}\text { G9a represses MAP1LC3B and } \\
\text { blocks autophagy }\end{array}$ & Glioblastoma & {$[39,40]$} \\
\hline & $\begin{array}{l}\text { G9a vacates autophagy related gene promoters } \\
\text { under starvation in vitro }\end{array}$ & $\begin{array}{c}\text { Cervical and } \\
\text { Pancreatic Cancer }\end{array}$ & {$[41]$} \\
\hline & $\begin{array}{c}\text { G9a blocks autophagy through activation } \\
\text { of mTOR }\end{array}$ & Gastric Cancer & [42] \\
\hline
\end{tabular}

G9a has also been linked to tumor growth and metastasis. In vitro studies using serial detachment and re-adhesion of Melan-A cells also found that H3K9me2 increased between non-metastatic mesenchymal-like melanoma cells, compared to the metastatic 
cells [34]. The detachment and re-adhesion of cells on a plate is a highly artificial model of epithelial-to-mesenchymal transition, but additional evidence for a role of G9a in melanoma metastasis can be found in other tumor types. In glioblastoma, G9a, along with other methyltransferases, can be sequestered by the lncRNA HOTAIRM1, which allows for the upregulation of HOXA1 to promote tumor growth [36]. The HOX genes are known to play a role in melanoma, with HOXA1 upregulation being indicative of highly metastatic tumors [35]. Additional evidence in breast cancer has shown that, during hypoxia, G9a represses $C D H 10$, a cell adhesion molecule, increasing cellular motility [37]. Since G9a can have activities associated with either promoting or suppressing metastatic behaviors, additional work is needed to assess whether G9a truly promotes metastasis through methylation, or if it acts as a repressor to HOX genes in melanoma, and whether these distinct activities may be dependent upon the context of other genomic aberrations within tumor cells, or perhaps within the microenvironment of the tumor.

Autophagy is another pathway that is perturbed by the modulation of G9a. In glioblastoma, G9a deficiency triggers autophagy and blocks proliferation through methylation of the $c-M Y C$ and MAP1LC3B1 promoters $[39,40]$. Similar findings have been found in cervical and pancreatic cell lines, where G9a is ejected from promoters of autophagy-related genes, including MAP1LC3B, under starvation conditions [41]. Additionally, G9a also blocks autophagy through $\mathrm{H} 3 \mathrm{~K} 9 \mathrm{me}$ of the $m T O R$ promoter in gastric cancer [42]. Though there is some evidence that G9a inhibition leads to the activation of autophagy through MAP1LC3B in melanoma [38], a more thorough assessment needs to be considered. Not only can autophagy be alternatively tumor suppressive or oncogenic, but additional parameters can conflate the role of G9a. Careful consideration must be given to factors including the concentration range of G9a inhibitors for optimal dosing and the timing required to induce long-term epigenetic alterations in chromatin accessibility, since short-term effects may not persist, as observed with the G9a lost in immune cells. It is also highly likely that the alternative consequences of autophagy modulation may be dependent upon the genomic context (including G9a status, as well as multiple others that remain to be identified).

As our understanding of G9a in melanoma continues to develop, it is apparent that the removal of repressive $\mathrm{H} 3 \mathrm{~K} 9 \mathrm{me} 2$ can have wide-ranging effects on multiple signaling pathways that can alter both tumors and the cells of the microenvironment. Within the field of melanoma epigenetics, there is much room for further study, to dissect additional pathways that can be leveraged to identify patients that may benefit from G9a inhibition. Additionally, understanding the full impact of G9a inhibition in combination with current melanoma therapies will be important moving forward.

\section{Targeting Histone Methyltransferases}

Another point of reference, to aid in our understanding of the role of G9a in melanoma, is the array of literature on EZH2, which is the target of the first FDA approved histone methyltransferase inhibitor, tazemetostat, for the treatment of epithelioid sarcoma [43]. In the early 2000s, EZH2, which methylates H3K27, was shown to be upregulated in breast cancer, prostate cancer, and lymphoma [44-46]. In these studies, the increased EZH2 expression was higher in proliferating cells, associated with poor outcomes for patients, or higher in metastatic samples compared to localized tumors. As the field advanced, a synthetic lethal relationship was described with mutant ARID1A, a member of the SWI/SNF chromatin remodeling complex, in ovarian cancer, where EZH2 silences autophagy in the absence of functional ARID1A [47]. EZH2 inhibition may also be a feasible treatment in gastric cancer, where ARID1A mutant tumors often have high levels of EZH2 [48]. As a paralog of ARID1A, ARID1B inhibition in medulloblastoma can also lead to increases in H3K27 methylation [49]. ARID1B is also a dependency in ARID1A mutant ovarian tumors, where a loss of both mutually exclusive subunits decreases the overall stability of the SWI/SNF complex [50]; together, this suggests that both paralogs can form a synthetic lethal relationship with EZH2 inhibition. However, this relationship is not found in urothelial bladder cancer, where ARID1A regulates cell cycle regression 
rather than the repression of EZH2 [51], indicating that tumor types and subtypes may need to be assessed individually. Understanding the role of EZH2 is ongoing, but EZH2 as a cancer therapy is well under way, with additional clinical trials testing tazemetostat and other EZH2 inhibitors for additional sarcoma subtypes (NCT02601950, NCT02601937), lymphoid neoplasms (NCT03603951, NCT04407741), and in combination with BRAF and MEK inhibition in melanoma (NCT04557956). It will be of interest to determine whether any clinical efficacy that is observed shows a correlation with the status of SWI/SNF subunit mutations. Together, these studies and the ongoing clinical trials highlight the need for in-depth analysis of the mechanism through which G9a promotes melanoma growth, and whether additional epigenetic regulators contribute to this process.

G9a inhibitors are still in the early stages of development. Currently, three compounds have been widely utilized as G9a inhibitors, with both BIX01294 and UNC0638 used in vitro, and UNC0642 tested in preclinical models in vivo, due to its more favorable pharmacokinetics. Additionally, G9a targeted therapies may help a wider range of melanomas, since the amplification of G9a occurs in the context of both BRAF- and NRAS-activating mutations, which are the two most common oncogenic drivers of melanoma [21]. Multiple studies have also indicated that G9a inhibition combination treatment might boost the response of melanoma to immune checkpoint inhibition in mouse models [21,38]. While these responses could be indicative of tumor-specific inhibition, there is still more work to be conducted to characterize if G9a inhibition is synergistic to immune checkpoint therapies.

\section{Conclusions}

The many roles of G9a, from the repression of stem cell factors in early development and CD4 during CD8+ T cell differentiation to inhibiting the DKK1 repression of Wnt signal in melanoma, highlight the broad range of functions that are controlled by the epigenetic regulation of histone methylation. As an emerging potential druggable target, G9a has been implicated in direct epigenetic effects in melanoma, to alter both Wnt and Notch signaling, as well as contributing to pathways that promote metastasis. Though the full effects of G9a are still under investigation, there are abundant resources to direct future research on G9a interactions with other epigenetic regulators, through inhibition studies, RNA interference, CRISPR knockouts, and mouse models, while taking into account the broader impact of G9a inhibition on tumor-associated fibroblasts and the immune components of the microenvironment. The broad, genome-wide effects of epigenetic factors, such as G9a, highlight the challenges in seeking anti-tumor efficacy without excessive toxicity. Yet, the presence of tumors containing the "smoking gun" of G9a mutations or amplifications may increase the therapeutic index (efficacy vs. toxicity) and further support the opportunity to therapeutically antagonize this enzyme. As an emerging target for melanoma therapy, G9a is another example of the importance of epigenetic regulation in our understanding of tumor biology.

Author Contributions: Conceptualization, J.L.F. and D.E.F.; data curation, J.L.F.; writing—original draft preparation, J.L.F.; review and editing, J.L.F. and D.E.F.; visualization, J.L.F; funding acquisition, D.E.F. All authors have read and agreed to the published version of the manuscript.

Funding: The authors gratefully acknowledge support from the following funding agencies: from NIH: P01CA163222; R01AR043369; R01CA222871; R01AR072304, and the Dr. Miriam and Sheldon G. Adelson Medical Research Foundation.

Conflicts of Interest: D.E.F. has a financial interest in Soltego, a company developing salt-inducible kinase inhibitors for topical skin-darkening treatments that might be used for a broad set of human applications. The interests of D.E.F. were reviewed and are managed by Massachusetts General Hospital and Partners HealthCare in accordance with their conflict of interest policies. 


\section{References}

1. Sigalotti, L.; Covre, A.; Fratta, E.; Parisi, G.; Colizzi, F.; Rizzo, A.; Danielli, R.; Nicolay, H.J.M.; Coral, S.; Maio, M. Epigenetics of human cutaneous melanoma: Setting the stage for new therapeutic strategies. J. Transl. Med. 2010, 8, 56. [CrossRef] [PubMed]

2. Dawson, M.A.; Kouzarides, T. Cancer epigenetics: From mechanism to therapy. Cell 2012, 150, 12-27. [CrossRef] [PubMed]

3. Barski, A.; Cuddapah, S.; Cui, K.; Roh, T.Y.; Schones, D.E.; Wang, Z.; Wei, G.; Chepelev, I.; Zhao, K. High-Resolution Profiling of Histone Methylations in the Human Genome. Cell 2007, 129, 823-837. [CrossRef] [PubMed]

4. Schaefer, A.; Sampath, S.C.; Intrator, A.; Min, A.; Gertler, T.S.; Surmeier, D.J.; Tarakhovsky, A.; Greengard, P. Control of Cognition and Adaptive Behavior by the GLP/G9a Epigenetic Suppressor Complex. Neuron 2009, 64, 678-691. [CrossRef] [PubMed]

5. Karimi, M.M.; Goyal, P.; Maksakova, I.A.; Bilenky, M.; Leung, D.; Tang, J.X.; Shinkai, Y.; Mager, D.L.; Jones, S.; Hirst, M.; et al. DNA methylation and SETDB1/H3K9me3 regulate predominantly distinct sets of genes, retroelements, and chimeric transcripts in mescs. Cell Stem Cell 2011, 8, 676-687. [CrossRef]

6. Peters, A.H.F.M.; O'Carroll, D.; Scherthan, H.; Mechtler, K.; Sauer, S.; Schöfer, C.; Weipoltshammer, K.; Pagani, M.; Lachner, M.; Kohlmaier, A.; et al. Loss of the Suv39h histone methyltransferases impairs mammalian heterochromatin and genome stability. Cell 2001, 107, 323-337. [CrossRef]

7. Sampath, S.C.; Marazzi, I.; Yap, K.L.; Sampath, S.C.; Krutchinsky, A.N.; Mecklenbräuker, I.; Viale, A.; Rudensky, E.; Zhou, M.M.; Chait, B.T.; et al. Methylation of a Histone Mimic within the Histone Methyltransferase G9a Regulates Protein Complex Assembly. Mol. Cell 2007, 27, 596-608. [CrossRef]

8. Bao, L.; Chen, Y.; Lai, H.T.; Wu, S.Y.; Wang, J.E.; Hatanpaa, K.J.; Raisanen, J.M.; Fontenot, M.; Lega, B.; Chiang, C.M.; et al. Methylation of hypoxia-inducible factor (HIF)-1 $\alpha$ by G9a/GLP inhibits HIF-1 transcriptional activity and cell migration. Nucleic Acids Res. 2018, 46, 6576-6591. [CrossRef]

9. Jan, S.; Dar, M.I.; Wani, R.; Sandey, J.; Mushtaq, I.; Lateef, S.; Syed, S.H. Targeting EHMT2/ G9a for cancer therapy: Progress and perspective. Eur. J. Pharmacol. 2021, 893, 173827. [CrossRef]

10. Rada, M.; Vasileva, E.; Lezina, L.; Marouco, D.; Antonov, A.V.; MacIp, S.; Melino, G.; Barlev, N.A. Human EHMT2/G9a activates p53 through methylation-independent mechanism. Oncogene 2017, 36, 922-932. [CrossRef]

11. Zeng, T.B.; Han, L.; Pierce, N.; Pfeifer, G.P.; Szabó, P.E. EHMT2 and SETDB1 protect the maternal pronucleus from $5 \mathrm{mC}$ oxidation. Proc. Natl. Acad. Sci. USA 2019, 166, 10834-10841. [CrossRef] [PubMed]

12. Wen, B.; Wu, H.; Shinkai, Y.; Irizarry, R.A.; Feinberg, A.P. Large histone H3 lysine 9 dimethylated chromatin blocks distinguish differentiated from embryonic stem cells. Nat. Genet. 2009, 41, 246-250. [CrossRef] [PubMed]

13. Filion, G.J.; Van Steensel, B. Reassessing the abundance of H3K9me2 chromatin domains in embryonic stem cells. Nat. Genet. 2010, 42, 4. [CrossRef] [PubMed]

14. Antignano, F.; Braam, M.; Hughes, M.R.; Chenery, A.L.; Burrows, K.; Gold, M.J.; Oudhoff, M.J.; Rattray, D.; Halim, T.Y.; Cait, A.; et al. G9a regulates group 2 innate lymphoid cell development by repressing the group 3 innate lymphoid cell program. J. Exp. Med. 2016, 213, 1153-1162. [CrossRef]

15. Gaballa, J.M.; Braga Neto, M.B.; Ramos, G.P.; Bamidele, A.O.; Gonzalez, M.M.; Sagstetter, M.R.; Sarmento, O.F.; Faubion, W.A. The Role of Histone Methyltransferases and Long Non-coding RNAs in the Regulation of T Cell Fate Decisions. Front. Immunol. 2018, 9, 2955. [CrossRef]

16. Verbaro, D.J.; Sakurai, N.; Kim, B.; Shinkai, Y.; Egawa, T. Cutting Edge: The Histone Methyltransferase G9a Is Required for Silencing of Helper T Lineage-Associated Genes in Proliferating CD8 T Cells. J. Immunol. 2018, 200, 3891-3896. [CrossRef]

17. Shin, H.M.; Kapoor, V.N.; Guan, T.; Kaech, S.M.; Welsh, R.M.; Berg, L.J. Epigenetic modifications induced by blimp-1 regulate CD8+ T cell memory progression during acute virus infection. Immunity 2013, 39, 661-675. [CrossRef]

18. Thomas, L.R.; Miyashita, H.; Cobb, R.M.; Pierce, S.; Tachibana, M.; Hobeika, E.; Reth, M.; Shinkai, Y.; Oltz, E.M. Functional Analysis of Histone Methyltransferase G9a in B and T Lymphocytes. J. Immunol. 2008, 181, 485-493. [CrossRef]

19. Nakajima, N.I.; Niimi, A.; Isono, M.; Oike, T.; Sato, H.; Nakano, T.; Shibata, A. Inhibition of the HDAC/Suv39/G9a pathway restores the expression of DNA damage-dependent major histocompatibility complex class I-related chain A and B in cancer cells. Oncol. Rep. 2017, 38, 693-702. [CrossRef]

20. Pereira, R.M.; Martinez, G.J.; Engel, I.; Cruz-Guilloty, F.; Barboza, B.A.; Tsagaratou, A.; Lio, C.W.J.; Berg, L.J.; Lee, Y.; Kronenberg, M.; et al. Jarid2 is induced by TCR signalling and controls iNKT cell maturation. Nat. Commun. 2014, 5, 4540. [CrossRef]

21. Kato, S.; Weng, Q.Y.; Insco, M.L.; Chen, K.Y.; Muralidhar, S.; Pozniak, J.; Diaz, J.M.S.; Drier, Y.; Nguyen, N.; Lo, J.A.; et al. Gain-of-function genetic alterations of g9a drive oncogenesis. Cancer Discov. 2020, 10, 980-997. [CrossRef] [PubMed]

22. Serre, C.; Busuttil, V.; Botto, J.-M. Intrinsic and extrinsic regulation of human skin melanogenesis and pigmentation. Int. J. Cosmet. Sci. 2018, 40, 328-347. [CrossRef] [PubMed]

23. Damsky, W.E.; Curley, D.P.; Santhanakrishnan, M.; Rosenbaum, L.E.; Platt, J.T.; Gould Rothberg, B.E.; Taketo, M.M.; Dankort, D.; Rimm, D.L.; McMahon, M.; et al. $\beta$-Catenin Signaling Controls Metastasis in Braf-Activated Pten-Deficient Melanomas. Cancer Cell 2011, 20, 741-754. [CrossRef]

24. Spranger, S.; Bao, R.; Gajewski, T.F. Melanoma-intrinsic $\beta$-catenin signalling prevents anti-tumour immunity. Nature 2015, 523, 231-235. [CrossRef] 
25. Kim, J.T.; Li, J.; Jang, E.R.; Gulhati, P.; Rychahou, P.G.; Napier, D.L.; Wang, C.; Weiss, H.L.; Lee, E.Y.; Anthony, L.; et al. Deregulation of Wnt/ $\beta$-catenin signaling through genetic or epigenetic alterations in human neuroendocrine tumors. Carcinogenesis 2013, 34, 953-961. [CrossRef]

26. Bergin, C.J.; Zouggar, A.; Haebe, J.R.; Masibag, A.N.; Desrochers, F.M.; Reilley, S.Y.; Agrawal, G.; Benoit, Y.D. G9a controls pluripotent-like identity and tumor-initiating function in human colorectal cancer. Oncogene 2021, 40, 1191-1202. [CrossRef]

27. Dang, N.N.; Jiao, J.; Meng, X.; An, Y.; Han, C.; Huang, S. Abnormal overexpression of G9a in melanoma cells promotes cancer progression via upregulation of the Notch1 signaling pathway. Aging 2020, 12, 2393-2407. [CrossRef]

28. Yang, Z.; Qi, Y.; Lai, N.; Zhang, J.; Chen, Z.; Liu, M.; Zhang, W.; Luo, R.; Kang, S. Notch1 signaling in melanoma cells promoted tumor-induced immunosuppression via upregulation of TGF- $\beta 1$. J. Exp. Clin. Cancer Res. 2018, 37, 1-13. [CrossRef]

29. Porcelli, L.; Mazzotta, A.; Garofoli, M.; Di Fonte, R.; Guida, G.; Guida, M.; Tommasi, S.; Azzariti, A. Active notch protects MAPK activated melanoma cell lines from MEK inhibitor cobimetinib. Biomed. Pharmacother. 2021, 133, 111006. [CrossRef]

30. Golan, T.; Levy, C. Negative regulatory loop between microphthalmia-associated transcription factor (MITF) and notch signaling. Int. J. Mol. Sci. 2019, 20, 576. [CrossRef]

31. Ma, W.; Han, C.; Zhang, J.; Song, K.; Chen, W.; Kwon, H.; Wu, T. The Histone Methyltransferase G9a Promotes Cholangiocarcinogenesis Through Regulation of the Hippo Pathway Kinase LATS2 and YAP Signaling Pathway. Hepatology 2020, 72, $1283-1297$. [CrossRef]

32. Shao, H.; Moller, M.; Cai, L.; Prokupets, R.; Yang, C.; Costa, C.; Yu, K.; Le, N.; Liu, Z.J. Converting melanoma-associated fibroblasts into a tumor-suppressive phenotype by increasing intracellular Notch1 pathway activity. PLoS ONE 2021, 16, e0248260. [CrossRef]

33. Du, Y.; Shao, H.; Moller, M.; Prokupets, R.; Tse, Y.T.; Liu, Z.J. Intracellular Notch1 Signaling in Cancer-Associated Fibroblasts Dictates the Plasticity and Stemness of Melanoma Stem/Initiating Cells. Stem Cells 2019, 37, 865-875. [CrossRef]

34. Azevedo, H.; Pessoa, G.C.; De Luna Vitorino, F.N.; Nsengimana, J.; Newton-Bishop, J.; Reis, E.M.; Da Cunha, J.P.C.; Jasiulionis, M.G. Gene co-expression and histone modification signatures are associated with melanoma progression, epithelial-to-mesenchymal transition, and metastasis. Clin. Epigenetics 2020, 12, 127. [CrossRef]

35. Maeda, K.; Hamada, J.I.; Takahashi, Y.; Tada, M.; Yamamoto, Y.; Sugihara, T.; Moriuchi, T. Altered expressions of HOX genes in human cutaneous malignant melanoma. Int. J. Cancer 2005, 114, 436-441. [CrossRef]

36. Li, Q.; Dong, C.; Cui, J.; Wang, Y.; Hong, X. Over-expressed lncRNA HOTAIRM1 promotes tumor growth and invasion through up-regulating HOXA1 and sequestering G9a/EZH2/Dnmts away from the HOXA1 gene in glioblastoma multiforme. J. Exp. Clin. Cancer Res. 2018, 37, 265. [CrossRef] [PubMed]

37. Casciello, F.; Al-Ejeh, F.; Miranda, M.; Kelly, G.; Baxter, E.; Windloch, K.; Gannon, F.; Lee, J.S. G9a-mediated repression of CDH10 in hypoxia enhances breast tumour cell motility and associates with poor survival outcome. Theranostics 2020, 10, 4515-4529. [CrossRef] [PubMed]

38. Kelly, G.M.; Al-Ejeh, F.; McCuaig, R.; Casciello, F.; Kamal, N.A.; Ferguson, B.; Pritchard, A.L.; Ali, S.; Silva, I.P.; Wilmott, J.S.; et al. G9a Inhibition Enhances Checkpoint Inhibitor Blockade Response in Melanoma. Clin. Cancer Res. 2021, 27, 2624-2635. [CrossRef] [PubMed]

39. Ciechomska, I.A.; Przanowski, P.; Jackl, J.; Wojtas, B.; Kaminska, B. BIX01294, an inhibitor of histone methyltransferase, induces autophagy-dependent differentiation of glioma stem-like cells. Sci. Rep. 2016, 6, 38723. [CrossRef]

40. Ke, X.X.; Zhang, R.; Zhong, X.; Zhang, L.; Cui, H. Deficiency of G9a Inhibits Cell Proliferation and Activates Autophagy via Transcriptionally Regulating c-Myc Expression in Glioblastoma. Front. Cell Dev. Biol. 2020, 8. [CrossRef] [PubMed]

41. Artal-Martinez de Narvajas, A.; Gomez, T.S.; Zhang, J.-S.; Mann, A.O.; Taoda, Y.; Gorman, J.A.; Herreros-Villanueva, M.; Gress, T.M.; Ellenrieder, V.; Bujanda, L.; et al. Epigenetic Regulation of Autophagy by the Methyltransferase G9a. Mol. Cell. Biol. 2013, 33, 3983-3993. [CrossRef] [PubMed]

42. Yin, C.; Ke, X.; Zhang, R.; Hou, J.; Dong, Z.; Wang, F.; Zhang, K.; Zhong, X.; Yang, L.; Cui, H. G9a promotes cell proliferation and suppresses autophagy in gastric cancer by directly activating mTOR. FASEB J. 2019, 33, 14036-14050. [CrossRef] [PubMed]

43. Mullard, A. FDA approves an inhibitor of a novel "epigenetic writer". Nat. Rev. Drug Discov. 2020, 19, 156. [CrossRef] [PubMed]

44. Varambally, S.; Dhanasekaran, S.M.; Zhou, M.; Barrette, T.R.; Kumar-Sinha, C.; Sanda, M.G.; Ghosh, D.; Pienta, K.J.; Sewalt, R.G.A.B.; Rubin, M.A.; et al. The polycomb group protein EZH2 is involved in progression of prostate cancer. Nature 2002, 419 , 624-629. [CrossRef]

45. Visser, H.P.J.; Gunster, M.J.; Kluin-Nelemans, H.C.; Manders, E.M.M.; Raaphorst, F.M.; Meijer, C.J.L.M.; Willemze, R.; Otte, A.P. The Polycomb group protein EZH2 is upregulated in proliferating, cultured human mantle cell lymphoma. Br. J. Haematol. 2001, 112, 950-958. [CrossRef]

46. Kleer, C.G.; Cao, Q.; Varambally, S.; Shen, R.; Ota, I.; Tomlins, S.A.; Ghosh, D.; Sewalt, R.G.A.B.; Otte, A.P.; Hayes, D.F.; et al. EZH2 is a marker of aggressive breast cancer and promotes neoplastic transformation of breast epithelial cells. Proc. Natl. Acad. Sci. USA. 2003, 100, 11606-11611. [CrossRef]

47. Bitler, B.G.; Aird, K.M.; Garipov, A.; Li, H.; Amatangelo, M.; Kossenkov, A.V.; Schultz, D.C.; Liu, Q.; Shih, I.M.; Conejo-Garcia, J.R.; et al. Synthetic lethality by targeting EZH2 methyltransferase activity in ARID1A-mutated cancers. Nat. Med. 2015, 21, 231-238. [CrossRef] 
48. Ashizawa, M.; Saito, M.; Min, A.K.T.; Ujiie, D.; Saito, K.; Sato, T.; Kikuchi, T.; Okayama, H.; Fujita, S.; Endo, H.; et al. Prognostic role of ARID1A negative expression in gastric cancer. Sci. Rep. 2019, 9, 6769. [CrossRef]

49. Deogharkar, A.; Singh, S.V.; Bharambe, H.S.; Paul, R.; Moiyadi, A.; Goel, A.; Shetty, P.; Sridhar, E.; Gupta, T.; Jalali, R.; et al. Downregulation of ARID1B, a tumor suppressor in the WNT subgroup medulloblastoma, activates multiple oncogenic signaling pathways. Hum. Mol. Genet. 2021, 30, 1721-1733. [CrossRef]

50. Helming, K.C.; Wang, X.; Wilson, B.G.; Vazquez, F.; Haswell, J.R.; Manchester, H.E.; Kim, Y.; Kryukov, G.V.; Ghandi, M.; Aguirre, A.J.; et al. ARID1B is a specific vulnerability in ARID1A-mutant cancers. Nat. Med. 2014, 20, 251-254. [CrossRef]

51. Garczyk, S.; Schneider, U.; Lurje, I.; Becker, K.; Vögeli, T.A.; Gaisa, N.T.; Knüchel, R. ARID1A-deficiency in urothelial bladder cancer: No predictive biomarker for EZH2-inhibitor treatment response? PLoS ONE 2018, 13, e0202965. [CrossRef] [PubMed] 